\title{
A data control framework for SAF-T reporting: A process-based approach
}

\section{Jerzy Auksztol ${ }^{1}$ iD, Magdalena Chomuszko²}

\begin{abstract}
We present an innovative process-based approach aimed at helping entrepreneurs to adapt to the new circumstances arising from the introduction of the Standard Audit File for Tax (SAF-T), which is changing the paradigm of tax authorities 3 in dealing with tax non-compliance. The responsibility to protect against evaders has shifted significantly from tax administration towards entrepreneurs, increasing the risk of financial penalties and torts. Simultaneously, it has enabled the introduction of innovative management concepts in the field of financial inspection, auditing, and tax compliance. A process-based approach has been proposed to cope with the complex challenges the entrepreneurs and accountants are now facing in this subject. It is used as a framework for combining key management concepts, like due diligence and quality management, which are typically applied separately. We have achieved our goal by constructing a Data Control Framework (DCF) for SAF-T that addresses the need for the redesign of internal financial control procedures to meet the new requirements of a fiscal audit. Two research methods have been used in this paper: (1) a survey to assess the effects of the implementation of the SAF-T standard in the enterprise and (2) design science research (DSR) for building the proposed framework. Keywords: Value Added Tax (VAT), VAT gap, VAT carousel, process-based approach, business process management, financial control, risk management, quality management, due diligence, Standard Audit File for Tax (SAF-T), dataset for accounting research, enterprise information systems, eXtensible Markup Language (XML)
\end{abstract}

\footnotetext{
1 Jerzy Auksztol, doctor habilitatus, prof. UG, University of Gdansk - Faculty of Management, ul. Armii Krajowej 101, 81-824 Sopot, Poland, e-mail: Jerzy.Auksztol@ug.edu.pl (ORCID ID: http://orcid.org/0000-0002-8138-6261).

2 Magdalena Chomuszko, Ph.D., Sage sp. z o.o., Al. Jerozolimskie 132, 02-305, Warsaw, Poland, e-mail: M.Chomuszko@gmail.com (ORCID ID: http://orcid.org/0000-0001-6498-2646)

3 In this paper, the following terms are used interchangeably: tax authorities, tax administration, and revenue body.
} 


\section{INTRODUCTION}

The Standard Audit File for Tax (SAF-T) is an open standard format based on eXtensible Markup Language (XML), which enables the storing and transferring of data for tax audit purposes. It was first published by the Organization for Economic Co-operation and Development (OECD) in 2005, with major amendments and extensions in 2010 (OECD, 2017b, p. 65). Revenue bodies in many countries have adopted this standard with great success, inter alia in Austria, France, Luxembourg, Lithuania, Norway, Poland, and Portugal. The relatively simple idea of sending financial records directly to the tax authorities has changed significantly the approach to audits on tax compliance. Its characteristics can be grouped in a four-fold way: (1) the reduction of burden by automation, (2) moving from collecting aggregates to individual records, (3) tax compliance process redesign, (4) increasing the taxpayer's responsibility for evaders' misconduct.

1) The reduction of burden by automation. It reflects the postulate to reduce tax compliance cost to a minimum (Braithwaite, 2013a, p. 1). SAF-T can optimize efficiently the mutual communication between taxpayers and revenue bodies. On the taxpayers' side, it is achieved by changing the features of the enterprise information system (EIS) ${ }^{4}$, where the functionality of exporting financial data to SAF-T has been built in by EIS developers. Therefore, this software can generate the required records and file them with the tax authorities via the Internet. The taxpayer's manual data feed is not needed anymore. On the opposite end, the tax administration automatically receives financial records from taxpayers and loads them into the administrative databases for further control, analysis and audit, eliminating manual or semi-manual, timeconsuming work.

2) Moving from collecting aggregates to individual records. SAF-T extends significantly the information scope available to revenue bodies without unnecessary delay. It helps build administrative registers consisting of individual records taken from different databases kept by taxpayers. For example, SAF-T for VAT collects data for each transaction carried out by VAT payers, which can be matched with corresponding records from their contractors. In consequence, the revenue body receives powerful tools to build a pool of cases earmarked for more precise and accurate fiscal auditing.

3) Tax compliance process redesign. Built by revenue bodies over the years, the system of tax audit based on collecting aggregates has changed significantly, mainly due to the possibility of direct access to the individual records of the whole population of taxpayers. Choosing individuals for

4 We assume that the enterprise information system consists, for example, of a financial accounting application. 
tax audit has become much more precise since the introduction of SAFT. Big Data technologies (Vasarhelyi, Kogan, \& Tuttle, 2015) and Business Intelligence analytics (Wu, Ou, Lin, Chand, \& Yen, 2012; OECD, 2017a, p. 38) which have been adopted by tax administration are also helpful in this field. This also opens the perspective for mitigating the negative effects of tax audit where a subjective interpretation may cause tension between an honest taxpayer and an inflexible tax inspector (Kirchler, Hoelzl, \& Wahl, 2008, p. 214-215).

4) Increasing the taxpayer's responsibility for evaders' misconduct. It mainly results from the very nature of value added tax (VAT), where (Ebrill, Keen, \& Bodin, 2001, p. 2) the tax is charged and collected throughout the production process, with provision for tax payable to be reduced by the tax paid in respect of purchases. It means that the tax paid by the final consumer is collected at each stage of the production and distribution chain. Taxpayers can reduce their tax by the amount paid earlier. This encourages sophisticated VAT frauds, which can involve honest taxpayers. It happens through the reduction of tax payable by the amount of tax shown in the documentation of the purchasing process, but in reality not paid by tax evaders and fraudsters. One of the methods of VAT fraud is called missing trader or carousel, discussed extensively in specialist literature (Ainsworth, 2006; Keen \& Smith, 2006). Another well-known mechanism is connected with the carbon allowance (Frunza, Guegan, \& Tchiebaut, 2010, p. 4), which can be traded on an electronic exchange market, thus increasing the fraud speed and volume. Tax authorities, in response to these kinds of frauds, have introduced changes to legislation that impose the tax liability on all participants involved in a transaction, even when some of them are unaware of the tax evasion. Collecting individual transaction records through SAF-T increases the compliance due to more accurate detection of all participants in fraudulent transactions.

This paper has two main objectives. The first one is to examine the accountants' attitude to changes caused by the introduction of the breakthrough SAF-T reporting. Accountants bear overall responsibility for tax compliance and build their own internal, accounting-focused procedures for fulfilling this task. Now, the changed circumstances have triggered a need to spread the responsibility for tax compliance to key employees performing processes involving vendors and purchasers. The accountants' attitude in this matter can be a motivation for research in the management field.

The second aim of this paper is to explore a Data Control Framework (DCF) for SAF-T, which helps entrepreneurs to build a resilient organization which responds in an agile way to the new circumstances arising from the introduction of SAF-T. Thus, we raise a discussion about the impact of SAF-T on decision processes executed at all levels of the economy: micro, mezzo, and macro. 
The main body of our study is divided into seven parts. Following the introduction, we identify the problem to be solved and set up the overall goal of DCF in the context of changing the relationship between entrepreneurs and tax authorities. In the third section, we present the theoretical background for constructing DCF, drawn from the process-based approach which integrates many useful management concepts investigated separately. We discuss business process management as an integration foundation, quality and risk management, together with tax due diligence and financial control. In the fourth section, we expound on the method used to achieve our goal. The building process of DCF is based on the widely recognized Design Science Research method. In the fifth section, we examine the research results consisting of (1) the survey analysis of the accountants' attitude to SAF-T, mostly responsible for tax compliance, and (2) the design of DCF. The sixth section demonstrates the usefulness and evaluates the suitability of the constructed DCF. The discussion and conclusion (sections seven and eight) summarize our study.

\section{THEORETICAL BACKGROUND}

In the theoretical investigation, we build the background for constructing our framework integrating many useful management concepts (Figure 6), which are explored separately elsewhere. The term framework we use after Shapira (2000, p. 1314) where: (...) it (1) provides a structure to organize observations, and (2) describes the structure in a clear and precise manner. At the beginning of this section, we explore the process-based approach as an integration foundation. Subsequently, we outline other concepts, i.e. quality management, risk management, tax due diligence, and internal financial control.

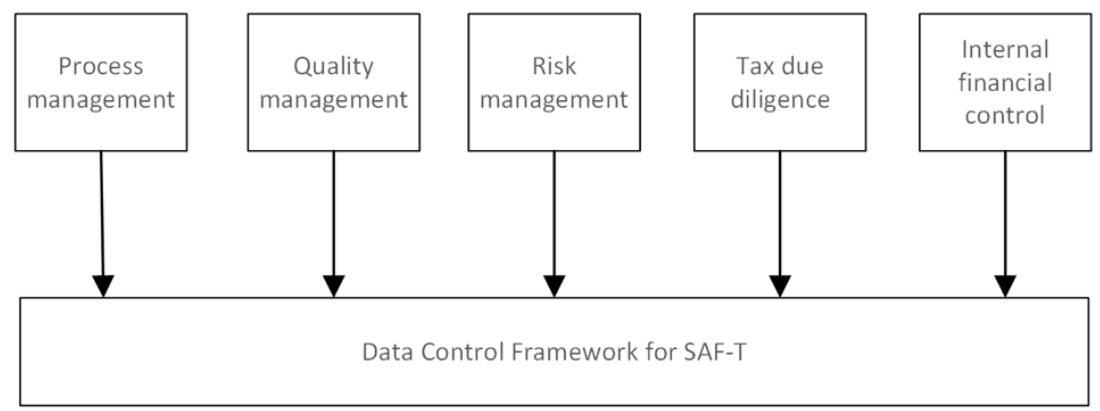

Figure 6. Components of the Data Control Framework for SAF-T 


\section{Process management}

Since the introduction of the business process reengineering concept outlined by Hammer (1990), Davenport (1993), and Hammer and Champy (1993), the idea of modeling the organization by means of processes has spread throughout academia and practice, building a foundation for a business process management discipline. Over almost three decades, it has matured, becoming a strategic means for constructing a competitive and resilient enterprise. However, the starting point of this idea can be found much earlier in Williams' (1967) paper where the author presented the concept of improving the production process efficiency by shortening its timespan and increasing the volume of production ${ }^{5}$. The debate about modeling the organizations by processes was saturated in response to the publications by Davenport (1993), Hammer (1990) and Champy (1993). The hype generated by the promising results of business process reformulating convinced many practitioners to implement it. Studies concentrating on critical success factors caused by the radical change in the organizations reported some difficulties in determining the real outcome as a success or failure (Larsen \& Myers, 1997). In the beginning, the financial indicators of the analyzed case displayed meaningful improvement, but later the implications were much more difficult. Rosemann (2014) explained this effect as a lack of a sufficient amount of methods supporting radical re-design and innovation in the organizational processes. The following decade showed a significant advancement in the theory and practice enriching the set of available process notations (e.g., Business Process Management Notation or Extension in Unified Modeling Language), process assessment tools (e.g., Six Sigma) and enterprise systems implementation (Sheer, 2000). Becker, Rosemann, and Uthmann (2002) presented some other fields where the process approach proved its value: lean management, activity-based costing, total quality management, process innovation, workflow management, and supply chain management. We would also like to extend this list with the capability maturity model (Van Looy, De Backer, \& Poels, 2011) business continuity management, and enterprise information systems' implementation.

In the literature, we can find a variety of definitions presenting many different directions of approaches to business process management. Swenson and von Rosing (2015) published a review of approximately 100 papers and put forward their proposal (p. 87) incorporating key thoughts found in the literature:

5 Williams' (1967) contribution explains to some extent the use of the term engineering in the organizational and social context, e.g. business process reengineering, although the Oxford Dictionary (2018b) defines it as the branch of science and technology concerned with the design, building, and use of engines, machines, and structures, which means that it is a pure technical, not an organizational matter. It confuses many scholars especially in the management field. 
Business process management (BPM) is a discipline involving any combination of modeling, automation, execution, control, measurement, and optimization of business activity flows in applicable combination to support enterprise goals, spanning organizational and system boundaries and involving employees, customers, and partners within and beyond the enterprise boundaries

This definition reflects the contribution of various scientists and development of the idea where the organization is analyzed by processes performed both internally and in relationships with external stakeholders. The problem stated in the second section of this paper may be solved in the process designed according to the discipline defined above.

The term process itself is defined in the literature in many ways. We take the classic proposal introduced by Davenport $(1993$, p. 5): A process is thus a specific ordering of work activities across time and place, with a beginning, an end, and clearly identified inputs and outputs: a structure for action.

We see our contribution here in using a process-based approach as the foundation for combining the many management concepts required to solve the increasingly complex challenges found in the changing social, organizational, legal, and technical environment that entrepreneurs are facing today.

\section{Quality management}

In defining the term data quality, we will follow the work presented in the paper by Wang and Strong (1996). They introduced a framework for capturing data quality (DQ) consisting of four dimensions (p. 6): (i) intrinsic $D Q$ grasping the essence of data content, (ii) contextual $D Q$ considering the task in which data are used, (iii) representational $D Q$ related to the form of presenting and using data and (iv) accessibility $D Q$ examining the way the data are approached. Subsequently, we will explore the first two dimensions for the purpose of constructing DCF. Two dimensions drawn in a hierarchical way examine intrinsic DQ: accuracy and objectivity. Following the ISO (1994) standard, we can extend the term accuracy to the following sentence: it is a measure of closeness of the financial records stored in the enterprise information system to the real economic events. The objectivity dimension, on the other hand, is strictly connected with the objectivity principle defined in accounting as a requirement that financial records are based on solid evidence. In our framework, it will also illustrate the solid evidence for tax purposes. The second discussed dimension is contextual $D Q$, which in our framework determines the use of each financial record for fiscal audit. 
We can now define the anticipated quality of financial records stored in enterprise information systems. It is the measure of accuracy, objectivity and context of data used in the process of a permanent fiscal audit using SAF-T data. In this context, SAF-T will be treated as the end product for quality assessment. To achieve an acceptable quality of financial records, we will use recommendations included in the concepts of quality and process management.

Introduced by Deming, Drucker, and Shewhart, the concept of quality management is broadly presented in the literature. Therefore, we assume the classic approach is grounded in theory and business practice. One of its main rules states that the end product's quality is determined by all the activities performed in the processes serving the construction of this product. This concept is derived from E. Deming's principle Improve process. Improve constantly and forever every process for planning, production, and service (Kanji, 1990). We can conclude from this rule that in quality management theoretical and practical movement, special attention was paid to the process management concept.

\section{Risk management}

The risk management approach is widely discussed in the literature on management, finance, working conditions, as well as natural disaster protection and safety (Lalonde \& Boiral, 2012). In our study, we use the normative perspective of risk management summarized in ISO 31000 (ISO 2009). It is connected with the previously set goal of achieving relevance and adjustment to the dynamic circumstances. The normative view is generally built on theory and practice in order to help practitioners structure their effort at unifying activities performed by many independent agents. ISO 31000 is divided into three main parts: principles, framework, and process. In the principles part, we can find sentences important from the DCF point of view, i.e.: (i) risk management is an integral part of all organizational processes and (ii) risk management is part of decision making. It means that at all stages of the activities performed in the context of specific processes, employers at all decision and operational levels use the risk management approach to identify, analyze, evaluate and treat non-compliance risks in a uniform way. The result of this approach is feeding the enterprise information system with correct, high-quality financial data that can be sent to the tax authorities.

\section{Tax due diligence}

Due diligence is a concept helpful in the provision of tax compliance. It was introduced by revenue authorities in the fiscal audit procedure in response to evaders exploiting legal loopholes. An additional factor raising the significance 
of this concept is the action taken by legislators. It extended the responsibility for the tax obligation to all participants involved in a transaction, where the VAT is not paid in the proper amount. The answer to this situation was to make entrepreneurs liable for the thorough investigation of each contractor. But at the same time, we can point out the legal restriction binding on entrepreneurs in fully performing such activities. Due diligence can help to mitigate the risks that result from establishing business relationships with unreliable contractors. The definition of due diligence can be found in online sources. According to the Oxford Dictionary (2018a), due diligence is reasonable steps taken by a person to avoid committing a tort or offense and we will use it as a background for ensuring tax compliance and call it tax due diligence.

\section{Internal financial control}

Internal financial control is the central part of DCF. Its goal is to fulfill the obligation to guarantee quality of data being entered into the enterprise information system. In defining this term, we follow the normative approach similar to the one presented in the case of risk management. After ICAEW ${ }^{6}$ (1994, p. 1), we define it as:

The internal control established in order to provide reasonable assurance of (a) the safeguarding of assets against unauthorized use or disposition; and (b) the maintenance of proper accounting records and the reliability of financial information used within the business or for publication.

This definition serves accurately the purpose of DCF because it focuses on proper accounting records. However, the introduction of SAF-T entailed the extension of the group of employees responsible for proper accounting data. From that moment, not only accountants but also employees involved in the purchase and sale processes are obliged to perform permanent financial control to ensure tax compliance.

\section{METHODOLOGY}

\section{Problem statement and research motivation}

As has been stated above, the introduction of SAF-T changed the relationships between revenue bodies and taxpayers significantly, strengthening the authorities' power but also opening the opportunities for improvements. The former manifests in the direct and automatic access to the individual records collected by taxpayers resulting in the more accurate detection of tax avoidance,

6 Institute of Chartered Accountants in England and Wales. 
evasion, and fraud. The implementation of SAF-T in the whole economy is not a one-step project. It is divided into many phases resulting in the future tight interface between the revenues' and taxpayers' information systems. The case of Poland (OECD 2017b, p. 66) shows that the approach exercised by tax offices is efficiency-oriented. In the beginning, it focused on VAT revenue because of: (1) increasing receipts from VAT in government income, (2) its susceptibility to fraud as well as (3) achievable semantic consistency.

The first decisive factor causing the focus on VAT in introducing SAF-T is increasing receipts from VAT in government income. This claim can be confirmed by analyzing statistical data published by the OECD (2017a) concerning the VAT share in the total tax revenue of OECD countries (Figure 1).

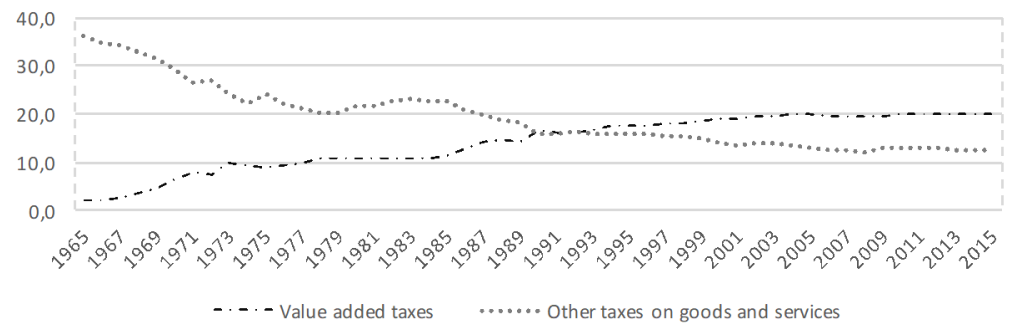

Figure 1. Trends in the consumption tax structure (1965-2015, as \% of total tax revenue)

Source: OECD (2017a, p. 24).

It can be noticed that VAT takes over the dominant position in consumption taxes, although the importance of other taxes, such as excise, remains substantial. Another trend highlighting the significance of VAT, seemingly not connected with consumption taxes, is the increasing share of social security contributions in total tax revenue (Figure 2).

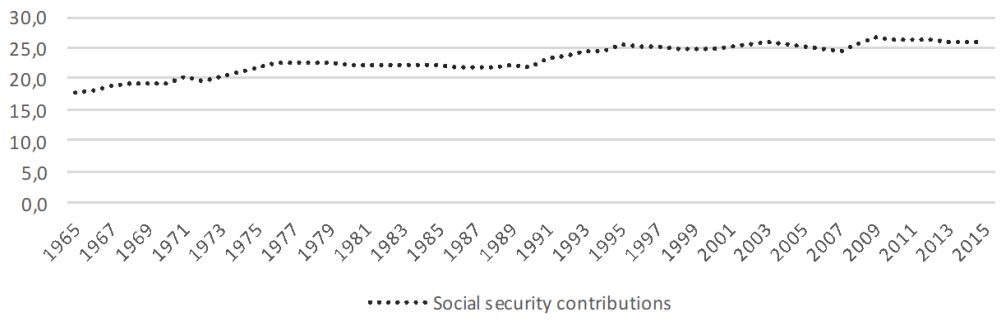

Figure 2. Social security contribution share in OECD countries (\% of total tax revenue)

Source: OECD (2017a, p. 24). 
Many developed countries are facing demographic problems, which will likely lead to the debate on shifting social contribution to consumption taxes (Thomas \& Picos-Sánchez, 2012; Pestel \& Sommer, 2013).

The second discussed factor is VAT's susceptibility to fraud. Its roots can be found in the design of VAT, where the taxpayers can reduce their tax payable by the amount paid earlier in the purchasing process ${ }^{7}$. The scope and intensity of this phenomenon are challenging to measure, but economists built some indicators to estimate it using aggregates delivered by the national account statistics. One of them is called VAT gap presented by Poniatowski, Bonch-Osmolovskiy, and Belkindas $(2016$, p. 15) in their acknowledged report. Another interesting material, discussing the VAT Revenue Ratio (VRR), was published by the OECD (2016b), where the analyses covered a long period. Further on, we will focus on the latter.

VRR is defined as the indicator calculated according to Formula 1.

$$
[\text { VAT Revenue Ratio }]=\frac{[\text { VAT Revenue }]}{([\text { Consumption }]-[\text { VAT revenue }] *[\text { [standard VAT rate }]}
$$

The interpretation of this indicator focuses on the deviation from value 1 which represents a desirable solution. It reflects the VAT revenue sourced from all consumption taxed at VAT standard rate. The values below 1 reflect exemptions, reduced VAT rates ${ }^{8}$ and, first and foremost, tax non-compliance resulting from calculation errors, avoidance, evasion, and fraud. The values above 1 inform that cascading VAT cannot be claimed for some products. Figure 3 presents the unweighted average of VRR for OECD countries over almost four decades from 1976 to 2014.

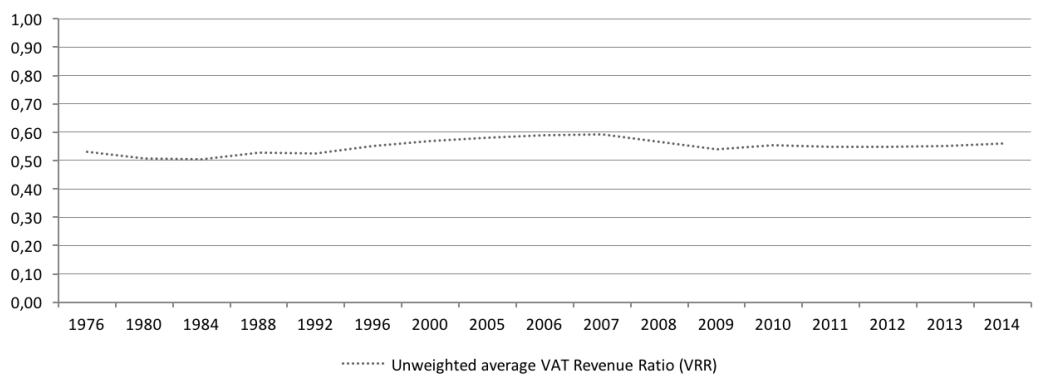

Figure 3. Unweighted average VAT Revenue Ratio for OECD countries Source: $\operatorname{OECD}(2016$, p. 118).

7 See Introduction section.

8 Application of reduced VAT rates has its ground in efficiency and social equity gains projected by government (Ebrill, Keen, \& Bodin, 2001, 68-82). 
Despite a stable trend in tax efficiency on a broader range, a deviation from the average will be subjected to further investigation. Figure 4 shows the VRR for selected OECD countries in 2014.

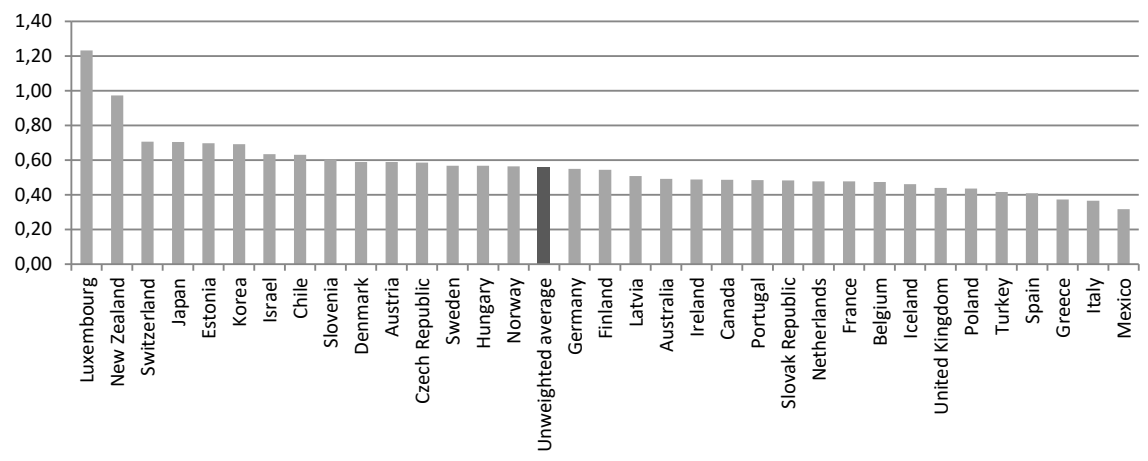

Figure 4. VAT Revenue Ratio for OECD countries in 2014 Source: OECD (2016, p. 118).

Luxembourg is the only country to record the results of VRR above value 1 . Moreover, it achieved a spectacular increase of 0.64 percentage points from the year 1976, not observed elsewhere. Other countries like New Zealand, Switzerland, Japan, Estonia, and South Korea are also successful in building an efficient system for VAT. The sources and causes of this approach were discussed by the OCED (2016).

The third factor which determined the choice of VAT for SAF-T reporting in the first place is achievable semantic consistency. Revenue authorities always strove to gather detailed information about each transaction performed in the economy, but the burden associated with manual collecting was overwhelming. However, the technological developments laid the grounds for the introduction of new ideas, viz. SAF-T, addressing the need to collect more precise records. One of these technological developments is the Internet's global spread. The vast majority of enterprises in the European Union (98\%) use fixed or mobile broadband Internet access (Figure 5).

Despite slight variations across countries (Lithuania - 100\%, France - 99\%, Austria - 98\%, Portugal - 98\%, Luxembourg - 97\%, Poland - $95 \%$, Norway -94\%), their tax authorities were able to introduce SAF-T with great success, because Internet access supported the whole process. 


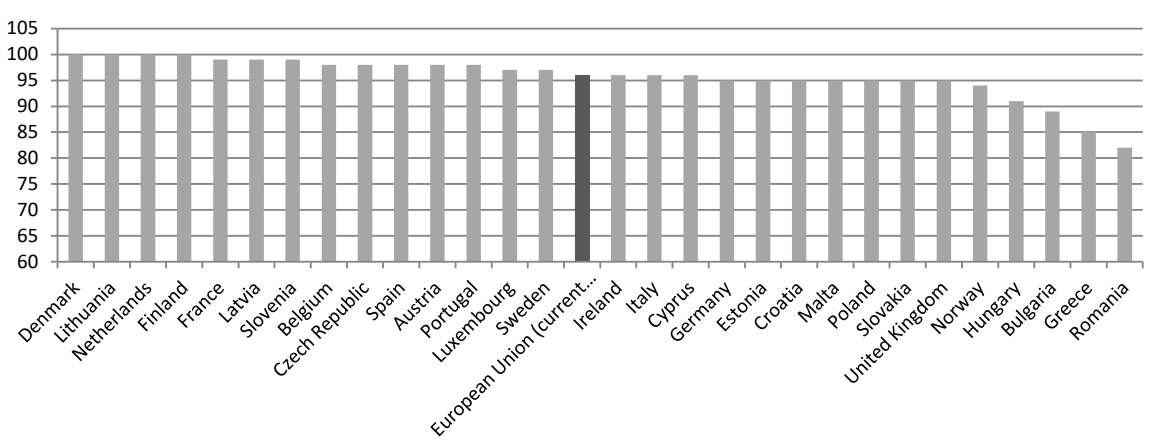

Figure 5. Proportion of enterprises using broadband access to the Internet (fixed or mobile) in the EU and Norway in 2017 (\%) Source: Eurostat (2018).

Another determinant of the smooth implementation of SAF-T, originally built by the OECD and associated organizations ${ }^{9}$, was its compatibility with the widespread XML open standard for data storage and communication. It allowed for the agile implementation of additional requirements regarding enterprise information systems to work with SAF-T. The crucial factor in such projects, where data collected from the whole population of enterprises are stored in one place, is the demand for semantic consistency. In the case of VAT, the use of unique identification of an enterprise through the National Business Registry Number can help meet the requirements for automatic matching and checking taxed turnover between contracting entities. Other sections of SAF-T, like balance sheet or profit and loss reports, require additional adjustment for automatic analysis. Each enterprise builds its own policy of registering economic events in accounting ledgers, causing the needs for individual, case-by-case analysis in tax audit control. Therefore, the tax administration in Poland introduced legislation that requires all enterprises, micro, small, medium and large to send periodically SAF-T generated returns from their VAT registers. On the other hand, the additional SAF-T sections, like inventory, bank operations, sales, and general ledger, are filed only on demand, probably in order to investigate each case separately, because an automatic search for patterns is limited due to the semantic inconsistency, for example, the same account number can be used for various purposes in different entities. Sophisticated tax avoidance methods are another barrier that can only be traced through individual fiscal audits. The development of artificial intelligence (Al) technology and the semantic standardization

9 i.e. Business Application Software Development Association and accounting bodies. 
of SAF-T returns obtained from different enterprises are ways to overcome these barriers in the future.

Concluding, we can claim that SAF-T has significantly changed the way tax authorities execute their power in monitoring tax compliance through the collection of financial records in one central place. It helps restrict the impact of avoidance, evasion, and fraud on VAT receipts. It also reduces the burden associated with filling in unnecessary declarations with aggregates, which can now be generated from individual financial records, stored in the submitted SAF-T data. Another benefit is the prospect of shorter tax refund times. It also fosters tracing transactions with unrecognized evaders and fraudsters.

At first glance, the introduction of SAF-T seems to be only a technical and organizational issue, but to a large degree, it is a fundamental breakthrough in the relationship between the revenue body and taxpayer, where the former gains more power through extended knowledge and the latter can expect fair treatment from objective auditing. It is also expected that at a macroeconomic level, fraud reduction will be perceptible. At an enterprise level, it generates the need for redesigning internal financial inspections to reduce the risks of providing the tax administration with incorrect SAF-T data or unwittingly establishing cooperation with tax evaders and fraudsters.

\section{Research method}

The first objective of our study presented in the Introduction section is accomplished through a survey that provides opinions on SAF-T implementation as expressed by an internet-based accounting discussion group. It is essential to assess these opinions in order to address and adjust the DCF design to the implied expectation. We are aware that these kinds of groups connect people who are mostly involved in tax compliance. The responses have been collected in a non-probability sampling survey where the results are not representative of the whole population. This can be used only for an approximation of the issue. For implementation of the second objective, namely constructing DCF, we employ the Design Science Research (DSR) widely discussed in research literature (Gregor \& Jones, 2007; Gregor \& Hevner, 2013). It guides us through the process of constructing the scientific artifact for entrepreneurs looking for the organizational concepts to improve the effectiveness and efficiency of a formal organization in the changing circumstance discussed above. In this context, we follow the procedure set up by Peffers, Tuunanen, Rothenberger, and Chatterjee (2007). 


\section{RESEARCH RESULTS AND DISCUSSION}

\section{Effects imposed by SAF-T implementation}

The aim of the study was to acquire knowledge about the accountants' subjective assessment of the effects imposed by SAF-T implementation in the enterprise. We hypothesize that they assess it mainly as additional cost-generating work due to the obligation of adapting the company to the requirements of SAF-T reporting, overlooking the opportunity to adjust their business processes to new circumstances. The survey was intended for the participants of the aforementioned discussion group and was carried out in March and April 2018. Forty-nine questionnaires were collected.

In the first question (Table 1), the respondents were asked to indicate the selected statement (seven multiple choices plus one open-ended question) related to SAF-T reporting.

As many as $69.4 \%$ indicated the first option, i.e. the increase in the amount of work related to the preparation of tax settlements. The secondranked answer results from the first one, as it implied incurring additional costs (item 2 with 40.8\%). The third answer, which referred to the benefits for the company from raising practical competences (using computer programs), was marked by $32.6 \%$ of the respondents. Only $6.1 \%$ pointed to the improvement of business management, which does not give ground for rejecting our hypothesis.

Table 1. The SAF-T implementation

\begin{tabular}{ll}
\hline Reporting via SAF-T entail the following results & Response structure (\%) \\
\hline $\begin{array}{l}\text { 1. Increased workload related to the preparation of tax } \\
\text { settlements }\end{array}$ & 69.4 \\
$\begin{array}{l}\text { 2. Incurring additional costs resulting from adapting the } \\
\text { company to the requirements of SAF-T reporting }\end{array}$ & 40.8 \\
$\begin{array}{l}\text { 3. Raising practical competences (using computer } \\
\text { programs) }\end{array}$ & 32.6 \\
$\begin{array}{l}\text { 4. Raising substantive competences (knowledge) } \\
\text { 5. Computerization of the enterprise }\end{array}$ & 24.5 \\
$\begin{array}{l}\text { 6. SAF-T reporting did not cause any changes in the } \\
\text { enterprise }\end{array}$ & 14.3 \\
7. Improvement of business management & 6.1 \\
8. Others & 2.0 \\
\hline
\end{tabular}

The analysis of the next question (Table 2) shows that the survey participants positively assessed the introduction of SAF-T reporting. 53.1\% 
of respondents considered it a good idea and $10.2 \%$ a very good idea. $30.6 \%$, however, had a negative attitude toward this concept (item 3 and 4), which requires further investigation.

Table 2. Subjective assessment of the SAF-T implementation concept

\begin{tabular}{lll}
\hline How do you assess the idea of reporting via SAF-T? & \multicolumn{2}{l}{ Response structure (\%) } \\
\hline 1. Very good idea & 10.2 & \\
2. Good idea & 53.1 & 63.3 \\
3. Bad idea & 18.4 & \\
4. Very bad idea & 12.2 & 30.6 \\
5. I have no opinion & 6.1 & 6.1 \\
\hline & $\mathbf{1 0 0 . 0}$ & $\mathbf{1 0 0 . 0}$ \\
\hline
\end{tabular}

Such responses, on the one hand, disclose a great awareness of the need for changes in tax settlements and, on the other, apprehension about costs and burden, without any benefits to the company. When asked: How do you assess the preparation of your company to the requirements of SAF-T?, 75.5\% of the respondents gave it the top marks (38.8\% - very good, $36.7 \%$ - good). Few (4.1\%) assessed the preparation of their company as insufficient (Table 3).

Table 3. Assessment of preparation to the SAF-T requirements

\begin{tabular}{llc}
\hline $\begin{array}{l}\text { How do you assess the preparation of your company to } \\
\text { the requirements of SAF-T? }\end{array}$ & \multicolumn{2}{l}{ Response structure (\%) } \\
\hline 1. Very good & 38.8 & \\
2. Good & 36.7 & 75.5 \\
3. Enough & 20.4 & 20.4 \\
4. Insufficient & 4.1 & 4.1 \\
5. I have no opinion & 0.0 & 0.0 \\
\hline
\end{tabular}

The last question (Table 4) in the survey concerns the concept of due diligence in respect to taxation (three multiple choices). Most respondents pointed to the following answer: tax due in SAT-F reporting means good practice that guarantees the correctness of data in the information systems and SAF-T (49\%). Second, $30.6 \%$ of the respondents stated that this is only a statutory requirement without practical significance. The smallest group of $20.4 \%$ responded that tax due diligence is a way to avoid liability in the event of entering into relationships with a dishonest contractor. 
Table 4. Perception of tax due diligence in SAF-T reporting

\begin{tabular}{ll}
\hline Due diligence is: & Response structure (\%) \\
\hline $\begin{array}{l}\text { 1. Good practice that guarantees the correctness of } \\
\text { data in the information systems and SAF-T }\end{array}$ & 50.0 \\
$\begin{array}{l}\text { 2. A statutory requirement without practical } \\
\text { significance }\end{array}$ & 31.3 \\
$\begin{array}{l}\text { 3. The legal requirements that exempt from liability } \\
\text { in the event of entering into relationships with }\end{array}$ & 20.8 \\
a dishonest contractor & \\
\hline
\end{tabular}

The above survey shows that a significant group of respondents focuses on a narrow area of issues related to SAF-T reporting or launching business controls, and some do not combine them with a wider business context.

\section{Data control framework design}

In this section, we follow the procedure of constructing an artifact called Data Control Framework (DCF) for SAF-T. It consists of five components: quality management, process management, risk management, tax due diligence, and financial control (Figure 6). They are used as a foundation for building a specific solution in a particular enterprise.

At a glance, fulfilling the legal obligation of sending SAF-T to the tax authorities requires solving the technical issue connected with adding functionality to the existing enterprise information systems. However, the previous discourse proved that it is not enough. The key point lies in the quality of data entered into the enterprise information systems, which generate the required SAF-T data and sending them to the appropriate authorities automatically. This latter action of the whole process must not be accomplished manually.

The documentation of SAF-T is the starting point towards the implementation of checkpoints for financial control (Figure 7).

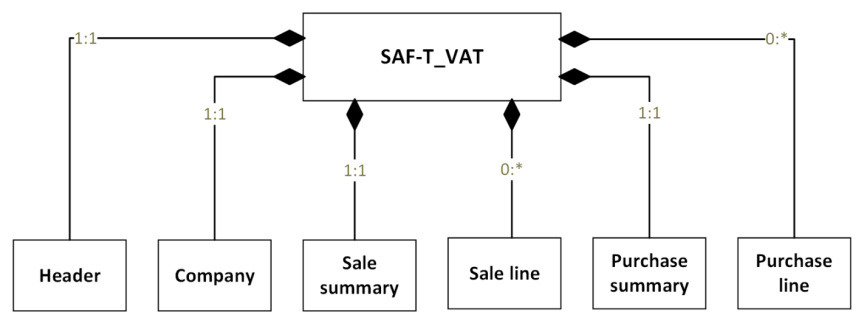

Figure 7. General schema of SAF-T_VAT

Source: own elaboration based on documentation of Ministry of Finance in Poland. 
The analysis of the graph indicates that the processes can be distributed under the following items:

- the selling process;

- the purchasing process;

- the process of managing basic data.

From this overall view of the process management approach, we can propose the points for performing financial control, e.g. inspection, and checking for tax compliance (Table 5).

Table 5. Data internal control workflow for SAF-T reporting - general view

\begin{tabular}{|c|c|c|c|c|}
\hline Process & Data & Inspection & EIS module & SAF-T section \\
\hline purchase & goods/stock/costs & $\begin{array}{l}\text { supplier/ } \\
\text { transaction }\end{array}$ & purchase & - \\
\hline $\begin{array}{l}\text { inventory } \\
\text { management }\end{array}$ & $\begin{array}{l}\text { receipts/release/ } \\
\text { transfer }\end{array}$ & $\begin{array}{l}\text { goods/ } \\
\text { transaction }\end{array}$ & inventory & inventory section of the SAF-T \\
\hline sale & income & $\begin{array}{l}\text { customer/ } \\
\text { transaction }\end{array}$ & sale & sales section of the SAF-T \\
\hline payment & $\begin{array}{l}\text { receipts/ } \\
\text { remittances }\end{array}$ & payments & banking & $\begin{array}{l}\text { bank operations section of the } \\
\text { SAF-T }\end{array}$ \\
\hline $\begin{array}{l}\text { financial } \& \\
\text { accounting }\end{array}$ & $\begin{array}{l}\text { data from all } \\
\text { modules of } \\
\text { the enterprise } \\
\text { information } \\
\text { system }\end{array}$ & data quality & $\begin{array}{l}\text { financial \& } \\
\text { accounting }\end{array}$ & $\begin{array}{l}\text { account books section of the } \\
\text { SAF-T } \\
\text { VAT settlement section of the } \\
\text { SAF-T }\end{array}$ \\
\hline
\end{tabular}

In the proposed DCF, data quality control is treated as an integral part of all processes identified in the enterprise corresponding to the product purchase, inventory management, sale and payment (Table 5). Analyzing purchases, data control should be added to the list of activities defined in the process called order materials and services (APQC 2018). One of the activities in this process is called record receipt of good and followed by research/ resolve exceptions (APQC 2018). These activities should verify conformity of the received goods with the invoice, documenting the delivery before entering data into the enterprise information systems. In terms of sales, the key processes manage sales orders (APQC 2018) and operate outbound transportation (APQC 2018) are the subjects for verifying the contractor's integrity, especially concerning export, where the VAT is zero-rated. In this case, all additional documents confirming delivery to the recipient, e.g. incurrence, waybill or delivery-note, are crucial to mitigate the risk.

Process mapping introduced in process-oriented management also helps to point out related processes which are important to identify additional 
risk of tax non-compliance, for example, manage customers and accounts (APQC 2018). In DCF, this process is responsible for identifying the risk of establishing a relationship with unreliable contractors. The above list does not cover all possible situations that may arise in the future. It should be verified in accordance with principles and foundation of risk analysis. According to the accounting rules, the financial control guarantees the data accuracy and objectivity from the perspective of data quality discussed in the subsection dedicated to quality management.

\section{Integration of the building blocks}

The course of action presented in the previous subsection leads us to the conclusion that each management concept contributes to the efficacy of DCF. It is mostly discoursed separately losing the whole picture of processes performed in the enterprise. Having in mind the need to solve real-life challenges, we proposed an integrated approach that combines key management methods in one unified foundation. This direction traces the path according to which the taxpayer guarantees reliable data in the enterprise information system (EIS), and thus in SAF-T. Figure 8 presents this path according to DCF.

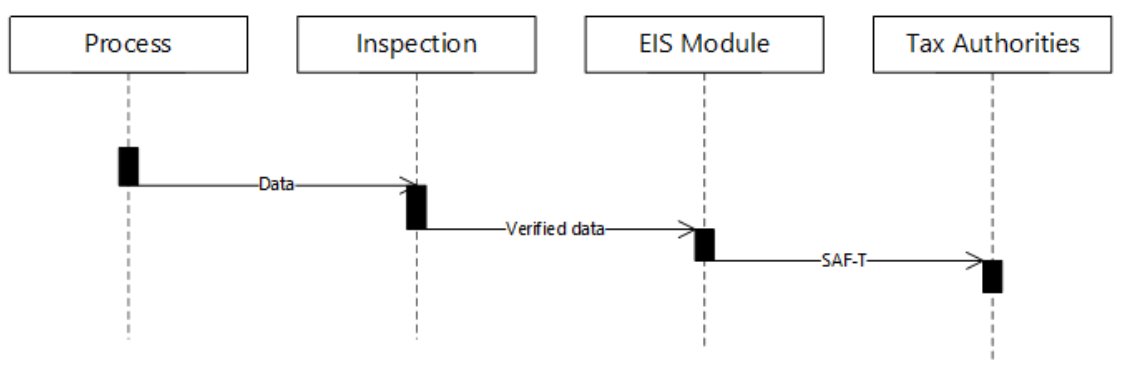

Figure 8. Workflow for SAF-T Reporting

Explaining the sequence of the presented actions, it is possible to identify their individual stages combined with the concept taken from DCF:

1) Identification of business processes (process management).

2) Design of procedures that implement processes for collecting data (process management).

3) Assessing the risk of non-compliance (risk management and due diligence).

4) Data control (quality management and financial control). 
5) Data recording in the enterprise information system (IT subject).

6) Transferring data from enterprise information system to SAF-T (IT subject).

7) Sending SAF-T to tax authorities (IT subject).

The identification of processes is mainly based on the documentation of SAF-T sections (Figure 7). They are comprehensible and can be used not only as a clue to identify processes but also as a support for designing procedures from the point of view of data needs for enterprise information system. This paper only discusses the sections of SAF-T_VAT, which is an example that can be used as a support to develop other processes related to SAF-T. The key action is data inspection understood as an assessment of the data quality from the perspective of accuracy, objectivity and its context. This step includes verification procedures for the indicated data documented by the taxpayer in case of inquiries from tax authorities.

DCF, in the last step, presents the supply of SAF-T sections with data obtained from the enterprise information system modules. However, from the taxpayer's point of view, this is a repetitive and generally automated activity, because its task is to take correct and compliant data from the enterprise information system. SAF-T is fed with the help of specific functionality of computer programs and the user does not perform these operations manually. If the goal of obtaining reliable data in the enterprise information system is achieved, then SAF-T will also be correct.

\section{Demonstration, evaluation, and communication}

The last step in constructing the artifact according to the Design Science Research rules is the demonstration of usefulness, evaluation of suitability, and presentation of communication. To accomplish this task, we discuss the case of public consultation which took place at the Parliament in Poland regarding the work performed by the Finance Ministry (Ministry) on the development of the taxpayers' approach to deal with non-compliance risk in relationships with contractors, after spreading the responsibility for unpaid tax to all parties, even the ones unwittingly involved in fraudulent transactions. We present DCF relevance by pointing out the correspondence between rules set up by the Ministry and DCF components.

The debate was initiated by Kulesza (2017) who submitted the following parliamentary questions:

- Is the Ministry planning a draft amendment to the Value Added Tax Act in which the definition of due diligence will be introduced? 
- Is the Ministry planning to issue clear and precise guidelines for entrepreneurs, specifying what actions they must take to exercise due diligence?

- What are the sources of information about the actions which entrepreneurs must take to exercise due diligence?

- Is investigative due diligence a sufficient method of appraising a business?

- What is the percentage distribution of the statement of due diligence or its lack in conducted tax inspection, which assessed this issue?

In response to the interpellation, the Deputy Minister of Finance pointed out that special care should be taken in case of any doubts when establishing relationships with a contractor. Further on, he provided examples of circumstances that may indicate a high risk of tax fraud. The Deputy Minister also mentioned that the Ministry is working on a list of due diligence criteria. These measures, however, face serious obstacles. Building a closed set of rules in the form of a standard or legal act is limited. It results from the significant diversification of economic relations that necessitate taking into account a different approach to due diligence.

The next step in creating a list of reasons for due diligence in the context of taxation was the announcement of tax consultations ${ }^{10}$. They resulted in 69 opinions received from taxpayers. On the basis of this material, the Ministry announced the preparation of a list that will serve taxpayers as a guideline for checking data to be entered into information systems. This would act e.g. as an instrument that will have a protective value for honest taxpayers.

Analyzing the material that was sent during the consultations, it is possible to claim that it contains valuable information and solutions that can be used not only for the purposes of VAT settlement. The most frequently repeated inspection activities that should be performed by the taxpayer in order to verify the data before entering them into enterprise information systems are:

- obtaining information about the taxpayer's legal status;

- verification of the entity in VAT administrative registers (e.g., VAT Information and Exchange System - VIES);

- verification of data reliability in relation to entries in other administrative business registers;

- checking the possession of required licenses and permits;

- checking the contractor's solvency, i.e. checking whether the contractors pay security contributions, taxes and whether they are registered in debt records;

10 Notification on the beginning of tax consultations of 30 June 2017. 
- verification of conformity of the received goods with the invoice documenting the delivery;

- verification of a bank account, whether it belongs to a given entity.

The above list presents an extended range of activities assigned to the following processes: (i) manage customers and accounts, (ii) order materials and services, and (iii) manage sales orders discussed in subsection Process management. The concept of risk management and tax due diligence helped to adjust process activities to the primary goal of mitigating the risk of establishing a relationship with an unreliable contractor.

As a result of this work, The Ministry of Finance in Poland (2108) published the document titled Methodology for the assessment of due diligence by purchasers of goods in domestic transactions. This document is hierarchically divided into three parts summarizing signals of risk grouped by the nature of activities performed by taxpayer in relationship with contractors.

1) Risk assessment at the start of cooperation.

2) Due diligence assessment during cooperation.

3) Due diligence assessment in a split payment transaction.

In Table 6, we give the list of signals for risk identification in the relationship with contractors in domestic transactions. It has a linear form because of its overlapping characteristics. The second column contains components of the Methodology... In the third column, we present the process compatible with DCF in which the identification of risk and further action of risk management should take place. It is also connected with the tax due diligence activities.

Some doubts visible in Table 6 need to be clarified. We have detected a contradiction to the theory of risk management in point 6 . According to this theory, the entrepreneurs are encouraged to mitigate risk encountered in their business but the recommendation of the Ministry says that no risk in business relationships can be accompanied by high risk of involvement in an evader's transaction. This contradiction needs further investigation especially in the field of entrepreneur's perception of superficial transaction circumstances built by evaders and speculators. In point 17 we can encounter the method of split payment not clarified earlier. It has been introduced by tax authorities and is applied in many countries. It is based on the principle that taxpayers split their payment into two parts - one, consisting of payment for goods or services, is transferred to the contractor and the other, being the amount of VAT, is transferred to the tax authorities which govern the correct tax settlement of transaction. 
Table 6. Recommendation for assessment of due diligence by purchasers of goods in domestic transactions

\begin{tabular}{|c|c|c|}
\hline $\begin{array}{l}\text { Signals of risk pointed out by Ministry of } \\
\text { Finance in Poland }\end{array}$ & $\begin{array}{l}\text { Category of } \\
\text { signal }\end{array}$ & $\begin{array}{l}\text { Place for recognition } \\
\text { in process map by } \\
\text { APQC v.7.20 }\end{array}$ \\
\hline $\begin{array}{l}\text { 1. Lack of contractor registration in administrative } \\
\text { registers, e.g. VAT Information and Exchange System - } \\
\text { VIES or National Official Business Register. }\end{array}$ & $\begin{array}{l}\text { 1. Risk } \\
\text { assessment } \\
\text { at the start of } \\
\text { cooperation. }\end{array}$ & $\begin{array}{l}\text { 3.5.2 Manage customers } \\
\text { and accounts. }\end{array}$ \\
\hline 2. Contractor is not registered as a VAT payer. & $\begin{array}{l}\text { 1. Risk } \\
\text { assessment } \\
\text { at the start of } \\
\text { cooperation. }\end{array}$ & $\begin{array}{l}\text { 3.5.2 Manage customers } \\
\text { and accounts. }\end{array}$ \\
\hline $\begin{array}{l}\text { 3. During the cooperation, the contractor was deleted } \\
\text { from the national VAT register. }\end{array}$ & $\begin{array}{l}\text { 2. Due diligence } \\
\text { assessment } \\
\text { during } \\
\text { cooperation. }\end{array}$ & $\begin{array}{l}\text { 3.5.4. Manage sales orders. } \\
\text { 4.2.4. Appraise and } \\
\text { develop suppliers. }\end{array}$ \\
\hline $\begin{array}{l}\text { 4. The contractor does not have, or - despite the } \\
\text { taxpayer's request - did not submit the required } \\
\text { concessions and permits for goods being the subject of } \\
\text { planned transactions. }\end{array}$ & $\begin{array}{l}\text { 1. Risk } \\
\text { assessment } \\
\text { at the start of } \\
\text { cooperation. }\end{array}$ & $\begin{array}{l}\text { 3.5.2 Manage customers } \\
\text { and accounts. }\end{array}$ \\
\hline $\begin{array}{l}\text { 5. Persons executing transactions do not have } \\
\text { authorization to act on behalf of a contractor. }\end{array}$ & $\begin{array}{l}\text { 1. Risk } \\
\text { assessment } \\
\text { at the start of } \\
\text { cooperation. } \\
\text { 2. Due diligence } \\
\text { assessment } \\
\text { during } \\
\text { cooperation. }\end{array}$ & $\begin{array}{l}\text { 3.5.2 Manage customers } \\
\text { and accounts. } \\
\text { 3.5.4. Manage sales orders. } \\
\text { 4.2.4. Appraise and } \\
\text { develop suppliers. }\end{array}$ \\
\hline $\begin{array}{l}\text { 6. The transaction was carried out without any } \\
\text { economic risk. }\end{array}$ & $\begin{array}{l}\text { 2. Due diligence } \\
\text { assessment } \\
\text { during } \\
\text { cooperation. }\end{array}$ & 3.5.4. Manage sales orders. \\
\hline $\begin{array}{l}\text { 7. The taxpayer made a payment in cash or benefited } \\
\text { from a price reduction in the case of cash payments } \\
\text { exceeding the limits specified in the statutes. }\end{array}$ & $\begin{array}{l}\text { 2. Due diligence } \\
\text { assessment } \\
\text { during } \\
\text { cooperation. }\end{array}$ & $\begin{array}{l}\text { 8.6.1. Process accounts } \\
\text { payable. }\end{array}$ \\
\hline $\begin{array}{l}\text { 8. The taxpayer paid for the goods by transfer to two } \\
\text { separate bank accounts for goods and VAT, a third- } \\
\text { party bank account or a foreign bank account in the } \\
\text { case of domestic delivery. }\end{array}$ & $\begin{array}{l}\text { 2. Due diligence } \\
\text { assessment } \\
\text { during } \\
\text { cooperation. }\end{array}$ & $\begin{array}{l}\text { 8.6.1. Process accounts } \\
\text { payable. }\end{array}$ \\
\hline $\begin{array}{l}\text { 9. The price of goods offered to the taxpayer by the } \\
\text { contractor deviates significantly from the market price } \\
\text { with no economic justification. }\end{array}$ & $\begin{array}{l}\text { 2. Due diligence } \\
\text { assessment } \\
\text { during } \\
\text { cooperation. }\end{array}$ & $\begin{array}{l}\text { 4.2.4. Appraise and } \\
\text { develop suppliers. }\end{array}$ \\
\hline $\begin{array}{l}\text { 10. The taxpayer purchased goods classified to } \\
\text { a different sector than that in which the seller } \\
\text { operates, when there is no economic reason for the } \\
\text { change of the seller's business profile. }\end{array}$ & $\begin{array}{l}\text { 2. Due diligence } \\
\text { assessment } \\
\text { during } \\
\text { cooperation. }\end{array}$ & $\begin{array}{l}\text { 4.2.4. Appraise and } \\
\text { develop suppliers. }\end{array}$ \\
\hline
\end{tabular}




\section{Signals of risk pointed out by Ministry of Finance in Poland \\ Category of signal}

11. The contractor has a registered office or place of business at the address where there were no signs of doing business.

1. Risk assessment at the start of cooperation.

12. The transaction was executed on conditions significantly different from those which were considered in the sector as ensuring the safety of trading.

13. The contractor delivered goods that do not meet the quality requirements specified in the generally applicable provisions of law. assessment during cooperation.

2. Due diligence assessment during
2. Due diligence 3.5.4. Manage sales orders. cooperation.

14. The transaction between the taxpayer and the 2. Due diligence contractor was not documented by a contract, order or assessment other confirmation of the terms of the transaction.

during cooperation.

15. The contractor being a capital company had at its disposal share capital disproportionately low in relation to the transaction circumstances or did not have organizational and technical facilities adequate to the type and scale of business operations.

16. The contractor does not have a website or is not present in social media with information relevant to the scale of the business, although it is customary in the sector in which the contractor operates.

1. Risk assessment at the start of cooperation.

1. Risk
assessment
at the start of
cooperation.
3. Due diligence
assessment in
split payment
transaction.

17. Transaction executed with split payment method, where the invoice: (a) was issued by non-existing entity, (b) acknowledges activities not performed, (c) contains amounts inconsistent with reality, (d) confirms actions to circumvent the legal act.
Place for recognition in process map by APQC v.7.20

3.5.2 Manage customers and accounts. 4.2.4. Appraise and develop suppliers.

4.2.4. Appraise and develop suppliers.

3.5.4. Manage sales orders. 4.2.4. Appraise and develop suppliers.

3.5.2 Manage customers and accounts.

Manage customers and accounts.

3.5.2 Manage customers and accounts. 3.5.4. Manage sales orders. 4.2.4. Appraise and develop suppliers.

8.2.2. Invoice customer. 8.2.3. Process accounts receivable.

8.6.1. Process accounts payable.

Source: own elaboration based on Ministry of Finance in Poland (2018) and APQC (2018).

This method increases the level of security but does not eliminate the risk of evaders' involvement, so point 17 recommends some actions. It should also be stated that split payment may have an adverse effect on liquidity by extending tax refund dates, which can be eliminated by smooth introduction of automatic processing of SAF-T executed by tax authorities. 


\section{CONCLUSION}

In this paper, we have proposed a framework built on the response to the need for a redesign of internal financial control procedures requiring adjustment to new conditions established after the introduction of the Standard Audit File for Tax (SAF-T) in dealing with external stakeholders like contractors and tax authorities. These conditions cover: (i) burden reduction in taxing by automation, (ii) moving from collecting aggregates to individual records, (iii) tax compliance process redesign and, (iv) increasing the taxpayer's responsibility for evaders' misconduct. The integrated approach included scientifically and practically grounded concepts, like tax due diligence, processes, and quality and risk management, together with financial control. It shaped the solution, demonstrated in the evaluation process, which can be effectively introduced by enterprises.

Data Control Framework (DCF) takes the complex, multidimensional challenges of the smooth introduction of SAF-T carried out in many countries. This solution combines many separate management concepts in one integrated approach based on the process-based foundation addressing the breakthrough made by SAF-T, not recognized by entrepreneurs, as our survey showed.

We constructed the framework by focusing on the relationships with the external stakeholders such as contractors and taxauthorities. Another research area in this field is a revision, which SAF-T can induce in financial controls and audit processes implemented in the internal structure of an enterprise composed of one or more legal entities. The use of open standards like XML enforced by legal obligation on producers of the enterprise information systems opened the unrestricted use of SAF-T. Financial data collected at the level of a single enterprise, corporate group, or tax administration, becomes ipso facto a new dataset, open for new management research.

The integrated approach used in DCF is a key concern in its structure. There are many management concepts focused only on one issue, missing the whole picture of mutually intertwined activities performed by an individual employee. We proposed to bridge this gap by applying the integrated approach based on the process-based foundation responding to the complex challenges and threats of current and future reality. Further on, DCF can be used as a framework for research on relationships between entrepreneurs and audit authorities including the tax administration. 


\section{Acknowledgments}

The authors would like to express their gratitude to the survey respondents who devoted their time and energy to complete the questionnaire, thus contributing to the accomplishment of the research.

\section{References}

Ainsworth, R. T. (2006). Carousel fraud in the EU: A digital VAT solution. Tax Notes International, 42(5), 443-448.

APQC (2018, January 8). Process Classification Framework version 7.2.0. American Productivity and Quality Framework. Retrieved from https://www.apqc.org/

Becker, J., Rosemann, M., \& von Uthmann C. (2000). Guidelines of business process modeling. In W. van der Aalst, J. Desel, \& A. Oberweis A. (Eds.), Business Process Management. Lecture Notes in Computer Science, 1806 (pp. 30-49). Berlin: Springer.

Braithwaite, V. (2003a). A new approach to tax compliance. In V. Braithwaite (Ed.), Taxing Democracy. Understanding Tax Avoidance and Tax Evasion (pp. 15-39). Aldershot: Ashgate.

Davenport, T. H. (1993). Process Innovation: Reengineering Work through Information Technology. Boston, MA: Harvard Business School Press.

Dennis, A. R., Carte T. A., \& Kelly, G.G. (2003). Breaking the rules: Success and failure in groupware-supported business process reengineering. Decision Support Systems, 36(1), 31-47. https://doi.org/10.1016/s0167-9236(02)00132-x

Ebrill, L. P., Keen, M., \& Bodin, J. P. (2001). The Modern VAT. Washington, D.C.: International Monetary Fund.

Eurostat (2018, January 8). Eurostat database. Table: Type of connections to the internet [isoc_ci_it_en2]. Variable: E_BROAD2 - Enterprises with broadband access (fixed or mobile). Retrieved from https://ec.europa. eu/eurostat/data/database/

Frunza, M. C., Guegan, D., \& Thiebaut, F. (2010). Missing trader fraud on the emissions market. Documents de travail du Centre d'Economie de la Sorbonne, 2010.71.

Gregor, S., \& Jones, D. (2007). The anatomy of a design theory. Journal of the Association for Information Systems, 8(5), 312-335. https://doi. org/10.17705/1jais.00129

Gregor, S., \& Hevner A. R. (2013). Positioning and presenting design science research for maximum impact. MIS Quarterly, 37(2), 337-355. https:// doi.org/10.25300/misq/2013/37.2.01

Hammer, M. (1990). Reengineering work: Don't automate, obliterate. Harvard Business Review, 78(1), 104-112.

Hammer, M., \& Champy, J. (1993). Business Process Reengineering. London: Nicholas Brealey.

ICAEW (1994). Internal Control and Financial Reporting -- Guidance for Directors of Listed Companies Registered in the UK. London: Institute of Chartered 
Accountants in England and Wales. Retrieved from https://www.icaew. com/-/media/corporate/files/library/subjects/corporate-governance/ internal-control-and-financial-reporting-rutteman-1994.ashx?la=en

ISO (1994). ISO 5725-1:1994 Accuracy (Trueness and Precision) of Measurement Methods and Results -- Part 1: General Principles and Definitions. Geneva: International Organization for Standardization.

ISO (2009). ISO 31000:2009 - Risk Management -- Principles and Guidelines. Geneva: International Organization for Standardization.

Kanji, G. K. (1990). Total quality management: The second industrial revolution. Total Quality Management, 1(1), 3-12. https://doi. org/10.1080/09544129000000001

Keen, M., \& Smith, S. (2006). VAT fraud and evasion: What do we know and what can be done? National Tax Journal, 69(4), 861-887. https://doi. org/10.5089/9781451865950.001

Kirchler, E., Hoelzl, E., \& Wahl, I. (2008). Enforced versus voluntary tax compliance: The 'slippery slope' framework. Journal of Economic Psychology, 29(2), 210-225. https://doi.org/10.1016/j.joep.2007.05.004 Kulesza, K. (2017, April 22). Interpretations, Inquiries, Questions and Deputies' Statements, Interpellation No 11813. Warsaw: The Parliament of the Republic of Poland (in Polish). Retrieved from http://www.sejm.gov.pl/ sejm8.nsf/interpelacje.xsp

Lalonde, C., \& Boiral, O. (2012). Managing risks through ISO 31000: A critical analysis. Risk Management, 14(4), 272-300. https://doi.org/10.1057/rm.2012.9

Larsen, M. A., \& Myers, M. D. (1997). BPR success or failure? A business process reengineering model in the financial services industry. In Proceedings of the International Conference on Information Systems (pp. 367-82). Retrieved from http://www.academia.edu/download/50514733/BPR success_or_failure_a_business_proces20161123-12879-w8c2zk.pdf

Ministry of Finance in Poland (2019, May 10). Methodology for the Assessment of Due Diligence by Purchasers of Goods in Domestic Transactions. Warsaw: Ministry of Finance in Poland (in Polish). Retrieved from https:// www.podatki.gov.pl/vat/bezpieczna-transakcja/nalezyta-starannosc/

OECD (2004). Compliance Risk Management: Managing and Improving Tax Compliance. Paris: Centre for Tax Policy and Administration.

OECD (2010). Forum on Tax Administration: Guidance and Specifications for Tax Compliance of Business and Accounting Software. Paris: Centre for Tax Policy and Administration.

OECD (2016a). Advanced Analytics for Better Tax Administration: Putting Data to Work. Paris: OECD Publishing. http://dx.doi. org/10.1787/9789264256453-en

OECD (2016b). Consumption Tax Trends 2016: VAT/GST and Excise Rates, Trends and Policy Issues. Paris: OECD Publishing. https://doi.org/10.1787/ctt-2016-en OECD (2017a). Revenue Statistics 1965-2016. Paris: OECD Publishing. https:// doi.org/10.1787/rev_stats-2017-4-en 
OECD (2017b). The Changing Tax Compliance Environment and the Role of Audit. Paris: OECD Publishing. https://doi.org/10.1787/9789264282186-en.

Oxford Dictionary (2018a, April 21). Oxford Dictionary - the term: due diligence. Retrieved from https://en.oxforddictionaries.com/definition/due_diligence Oxford Dictionary (2018b, April 24). Oxford Dictionary - the term: engineering. Retrieved from https://en.oxforddictionaries.com/definition/engineering

Peffers, K., Tuunanen, T., Rothenberger, M. A., \& Chatterjee, S. (2007). A design science research methodology for information systems research. Journal of Management Information Systems, 24(3), 45-77. https://doi. org/10.2753/mis0742-1222240302

Pestel, N., \& Sommer, E. (2013). Shifting taxes from labor to consumption: Efficient, but regressive? IZA Discussion Paper, no. 7804. Bonn: Institute for the Study of Labor (IZA).

Poniatowski, G., Bonch-Osmolovskiy, M., \& Belkindas, M. (2016). Study and Reports on the VAT Gap in the EU-28 Member States: 2016 Final Report. Warsaw: Center for Social and Economic Research and Institute for Advanced Studies.

Rosemann, M. (2014). Proposals for future BPM research directions. In C. Ouyang, \& J. Y. Jung (Eds.). Asia Pacific Business Process Management. AP-BPM 2014. Lecture Notes in Business Information Processing (181, pp. 1-15). Cham: Springer.

Scheer, A.-W. (2000). ARIS - Business Process Modeling. Berlin: Springer-Verlag. Shapira, Z. (2011). "I've Got a theory paper-do you?": Conceptual, empirical, and theoretical contributions to knowledge in the organizational sciences. Organization Science, 22(5), 1312-1321. https://dx.doi.org/10.1287/ orsc. 1100.0636

Swenson, K. D., \&, von Rosing, M. (2015). Phase 4: What is business process management? In M. von Rosing, H. von Scheel, \& A.-W. Scheer (Eds.). The Complete Business Process Handbook. Body of Knowledge from Process Modeling to BPM (I) (pp. 79-88). Waltham: Morgan Kaufmann Publishers.

Thomas, A., \& Picos-Sánchez, F. (2012). Shifting from social security contributions to consumption taxes: The impact on low-income earner work incentives. OECD Taxation Working Papers, 11.

Van Looy, A., De Backer, M., \& Poels, G. (2011). Defining business process maturity. A journey towards excellence. Total Quality Management, 22(11), 1119-1137. https://doi.org/10.1080/14783363.2011.624779

Vasarhelyi, M. A., Kogan, A., \& Tuttle, B. M. (2015). Big data in accounting: An overview. Accounting Horizons, 29(2), 381-396. https://doi.org/10.2308/ acch-51071

Wang, R. Y., \&, Strong, D. M. (1996). Beyond accuracy: What data quality means to data consumers. Journal of Management Information Systems, 12(4), 5-33. https://doi.org/10.1080/07421222.1996.11518099

Williams, S. (1967). Business process modeling improves administrative control. Automation, 44-50. Retrieved from https://www.econbiz.de/ 
Record/business-process-modeling-improves-administrative-controlchestnut-harold/10002001276

Wu, R. S., Ou, C. S., Lin, H., Chang, S. I., \& Yen, D. C. (2012). Using data mining technique to enhance tax evasion detection performance. Expert Systems with Applications, 39(10), 8769-8777. https://doi.org/10.1016/j. eswa.2012.01.204

\begin{abstract}
Abstrakt
W artykule prezentujemy innowacyjne podejście o charakterze procesowym majqce na celu wsparcie przedsiębiorców w dostosowaniu się do nowych okoliczności powstałych po wprowadzeniu raportowania przy użyciu Jednolitego Pliku Kontrolnego (JPK), powodujqcego istotnq zmianę stanowiska urzędów skarbowych w postępowaniach o unikaniu opodatkowania. Ciężar przeciwdziałania temu procederowi przeniesiono z administracji podatkowej na przedsiębiorców, zwiększajq̨c tym samym ryzyko kar finansowych i odpowiedzialności deliktowej. Jednak w tym samym momencie otworzyły się nowe możliwości wprowadzenia innowacyjnych koncepcji zarzqdzania w zakresie kontroli finansowej, audytu i zgodności podatkowej. Aby sprostać tym wyzwaniom wykorzystywano podejście procesowe jako platformę integrujqca kluczowe koncepcje zarzadzania ryzykiem i jakościq oraz należytej staranności, które powszechnie analizowane były rozłącznie. Cel nasz osiqgnnęliśmy opracowujq̨c Szablon Postępowania przy Kontroli Danych dla JPK, który zaspokaja potrzebę wprowadzenie procedur wewnętrznej kontroli finansowej odpowiadajqcej nowym wymaganiom kontroli skarbowej. W pracy wykorzystano dwie metody badawcze: (1) badanie ankietowe oceniajace efekty wdrożenia standardu JPK w przedsiębiorstwie oraz (2) podejście projektowe umożliwiajqce opracowanie rzeczonego szablonu postępowania.

Słowa kluczowe: Podatek od Wartości Dodanej (Value Added Tax - VAT), luka VAT, karuzela VAT, podejście procesowe, zarzqdzanie procesami biznesowymi, kontrola finansowa, zarzq̨dzanie ryzykiem, zarzq̨dzanie jakościq, należyta staranność, Jednolity Plik Kontrolny (JPK), systemy zarzqdzania przedsiębiorstwem, Rozszerzony Język Znaczników (eXtended Markup Language - XML)
\end{abstract}

\title{
Biographical notes
}

Jerzy Auksztol, Associate Professor at the Faculty of Management, University of Gdansk (Poland). His main research interest focuses on information system and technology management, process-based approach, as well as, IT project management. He has published numerous journal publications, conference papers, books, and book chapters.

Magdalena Chomuszko, Ph.D. in management science (economics discipline). She is employed by Sage sp. z o.o. located in Poland and is responsible for consulting in the field of ERP systems, SAF-T implementation, and business intelligence matters. 